\title{
Minimal invasive laser treatment for female stress urinary incontinence
}

\begin{abstract}
Objectives: Stress urinary incontinence (SUI) is common health problem and affects quality of life. This study was designed to evaluate minimal invasive laser as treatment option for female SUI.

Patients and methods: Fifty (50) women with SUI were included in this study which was conducted over one year. A specially designed laser speculum was introduced into women's vagina to serve as a guide for insertion of hand piece for irradiation of anterior vaginal wall. Second phase of the IncontiLaseTM procedure was performed on the vestibule and introitus. Preoperative and 6 months post-operative urodynamic studies were done for all studied women.
\end{abstract}

Results: Average flow rate was significantly improved from $3 \mathrm{ml} / \mathrm{second}$ before treatment to $11 \mathrm{ml} / \mathrm{second}$ after laser treatment and voiding time was also significantly improved from 9 seconds before treatment to 24 seconds after treatment. Residual urine volume was significantly increased from $17 \mathrm{ml}$ before treatment to $38 \mathrm{ml}$ after treatment, and first sensation was also significantly increased from $54 \mathrm{ml}$ before treatment to $122 \mathrm{ml}$ after treatment. First desire was desire was significantly increased from $75 \mathrm{ml}$ before treatment to $180 \mathrm{ml}$ after treatment and strong desire was also significantly increased from $150 \mathrm{ml}$ before treatment to $250 \mathrm{ml}$ after treatment. Maximal uretheral closure pressure was significantly increased from $16 \mathrm{~cm} \mathrm{H}_{2} \mathrm{O}$ before treatment to $34 \mathrm{~cm} \mathrm{H}_{2} \mathrm{O}$ after treatment.

Conclusion: Minimal invasive laser is outpatient procedure, has the advantage of improving of SUI symptoms without any possible complications as bladder perforation or hematoma. Also, it improves vaginal mucosa tone, regenerates collagen and collagen regains its power to contract with subsequent stabilization of bladder neck.

Keywords: laser, stress urinary incontinence, urodynamic assessment
Volume 2 Issue 2 - 2015

\author{
Assem AM Elbiaa, ${ }^{2}$ Ibrahim A Abdelazim, ${ }^{3}$ \\ Hussain $M,{ }^{4}$ Mohamed M Khalafalla' \\ 'Lecturer of Obstetrics and Gynecology, Menofia University, \\ Egypt \\ ${ }^{2}$ Assistant professor of Obstetrics \& Gynecology, Ain Shams \\ University, Egypt \\ ${ }^{3}$ Professor of Obstetrics and Gynecology, Ain Shams University, \\ Egypt \\ ${ }^{4}$ Lecturer of Obstetrics and Gynaecology, Ain Shams University, \\ Egypt
}

Correspondence: Mohamed M Khalafalla, Lecturer of Obstetrics and Gynecology, Menofia University, Menofia, Egypt, Email Khalafalah2006@yahoo.com

Received: March 13,2015 | Published: April 14, 2015
Abbreviations: SUI, stress urinary incontinence; CMC, consultation medical clinic; TVTO, trans-obturator tape; TVT, transvaginal free tape.

\section{Introduction}

Stress Urinary Incontinence (SUI) is leakage of urine when abdominal pressure increased during; sneezing, coughing, physical exercise, lifting, bending and even changing positions. ${ }^{1}$ Two principal causes of urine leak during increased abdominal pressure; SUI and stress-induced detrusor over activity, which involves involuntary detrusor contractions when abdominal pressure increased. ${ }^{2}$ SUI has negative impact on patient's quality of life; affecting day to day activities, participation in sports and sexual activity. Consequently, it is important for the healthcare provider to discuss these issues with the patient to determine how bothered she is by SUI and to dispel some common myths associated with SUI. ${ }^{3}$ There are many treatment options and the healthcare provider should have deep conversation with the patients to counsel them about various treatment options, outcomes and possible risks. ${ }^{4}$ There are many possible nonsurgical and surgical therapies for SUI. ${ }^{5}$ Initial treatment should include nonsurgical behavioral changes and pelvic floor muscle exercises. Electrical stimulation, weighted vaginal cones and drug therapy may reduce SUI. Bulking agents reduce leakage, but effectiveness generally decreases after $1-2$ years. ${ }^{6}$ Surgical procedures are more likely to cure stress urinary incontinence than nonsurgical procedures but are associated with complications and prolonged hospital stay. Many women with SUI do not seek care for their condition because of embarrassment, lack of knowledge about possible treatments or fear that treatment will require surgery. ${ }^{7}$ Several studies have shown that if less invasive treatments become more available, more patients may be willing to seek care without fear of surgery. ${ }^{4}$ Many researchers are therefore searching for a minimally invasive treatment that offers good efficacy, safety and a short recovery period. ${ }^{8}$ The effects of lasers are well established in terms of biochemical, ablative and thermal effects. Thermal energy from the laser source, especially in moist environments, enhances collagen structure and stimulates neocolagenesis. ${ }^{9}$ As a result of laser irradiation the intermolecular cross links of the triple helix of collagen shorten, which leads to the immediate tightening of collagen fibrils by two thirds of their length in comparison to the pre intervention state. Previous experimental and clinical studies have shown significant effects of laser treatment in various conditions deriving from collagen damage. ${ }^{5}$ IncontiLaseTM is minimally invasive laser techniques that enable collagen remodeling with subsequent improvement of SUI symptoms and pelvic floor muscle strength and quality of life. ${ }^{10,11}$ This study was designed to evaluate minimal invasive laser as treatment option for female SUI.

\section{Patients and methods}

Fifty (50) women with SUI were included in this prospective cohort study which was conducted over one year from May 2013 to May 2014 in Consultation Medical Clinic (CMC), Aljahra hospital, Kuwait after informed consent and approval of the study by institute ethical committee. SUI was diagnosed by patients symptoms, urine analysis and urodynamic studies. The urodynamic assessment include; uro- 
flowmetry, both filling (at a rate of $60 \mathrm{ml} / \mathrm{min}$ of $35^{\circ} \mathrm{C}$ distilled water), voiding cystometry when bladder filled with amount of distilled water and stress urethral pressure profile through withdrawal of dual lumen fluid-filled catheter, connecting to the external transducers at rate of $0.5 \mathrm{~mm} / \mathrm{second}$ when patient's strong-desire from filled bladder occurs.

Women with urinary tract infection, urge incontinence, mixed incontinence, neuropathic diseases or pelvic muscle diseases, pregnant women or women with over 70 years, severe stress urinary incontinence, advanced genital prolapse, intake of photosensitive drugs and injury and/or active infection in treatment area were excluded from this study. Menstruating women, pregnant women or women with undiagnosed uterine bleeding were also excluded from this study.

A specially designed laser speculum was introduced into women's vagina to serve as a guide for insertion of hand piece with an angular adapter which enables a precise irradiation of anterior vaginal wall. The second phase of the IncontiLaseTM procedure is performed on the vestibule and introits area. Preoperative and 6 months postoperative urodynamic studies were done for all studied women. Validated questionnaires of the International Consultation on Incontinence (Short-Arabic Form) and quality of life were filled by all studied women. Pre-treatment and 6 months post-treatment data were collected and statistically analyzed. No additional therapy was given to all studied women during laser treatment and 6 months after.

The IncontiLaseTM procedure treatment consisted of two phases; during first phase, before laser treatment, patient's vagina (vestibule, introitus and vaginal canal) was thoroughly washed by antiseptic solution and dried to remove antiseptic solution and mucus. A specially designed laser speculum was introduced into women's vagina (Figure 1) to serve as a guide for insertion of hand piece with an angular adapter which enables a precise irradiation of the anterior vaginal wall through delivery of a fractional Er: YAG laser beam (Figure 2). Laser energy is applied along anterior vaginal wall in several longitudinal passes, deposited successively along vaginal canal without overlapping, by simple step by step withdrawal of laser hand piece outwards from the laser speculum. Laser energy of delivered to each irradiation location according to manufacturer's instructions (Fotona, Slovenia), (Figure 3 ), producing thermal effect on the mucosa tissue and endo-pelvic fascia of vaginal wall that causes shrinkage of collagen of vaginal mucosa. ${ }^{12}$

\section{Results}

IncontiLaseTM procedures were successfully completed as outpatient procedure with 36 minutes average treatment time and more than $50 \%$ of studied women experienced no pain during treatment while $50 \%$ experienced mild pain. All studied women returned immediately after laser treatment to routine normal daily activity (Figure 4).

Average flow rate was significantly improved from $3 \mathrm{ml} /$ second before treatment to $11 \mathrm{ml} / \mathrm{second}$ after laser treatment and voiding time was also significantly improved from 9 seconds before treatment to 24 seconds after laser treatment (Table 1). Residual urine volume was significantly increased from $17 \mathrm{ml}$ before treatment to $38 \mathrm{ml}$ after laser treatment, and first sensation was also significantly increased from $54 \mathrm{ml}$ before treatment to $122 \mathrm{ml}$ after treatment. First desire was desire was significantly increased from $75 \mathrm{ml}$ before treatment to $180 \mathrm{ml}$ after treatment and strong desire was also significantly increased from $150 \mathrm{ml}$ before treatment to $250 \mathrm{ml}$ after laser treatment (Table 2). Maximal urethral closure pressure was significantly increased from $16 \mathrm{~cm} \mathrm{H}_{2} \mathrm{O}$ before treatment to $34 \mathrm{~cm} \mathrm{H}_{2} \mathrm{O}$ after laser treatment (Table 3).

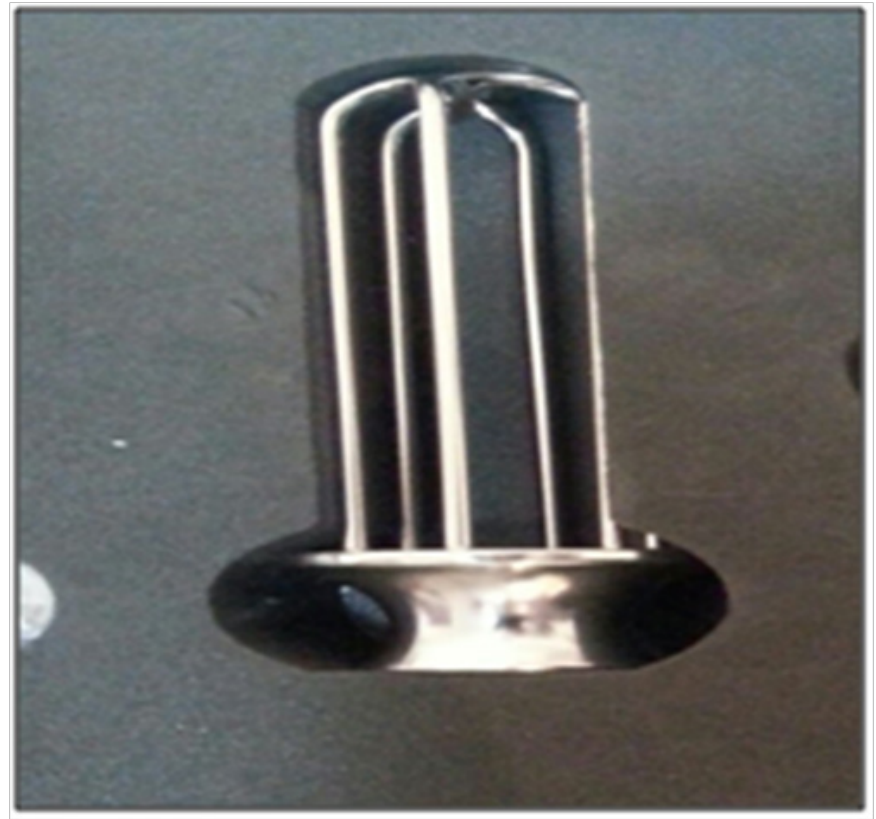

Figure I Vaginal speculum.

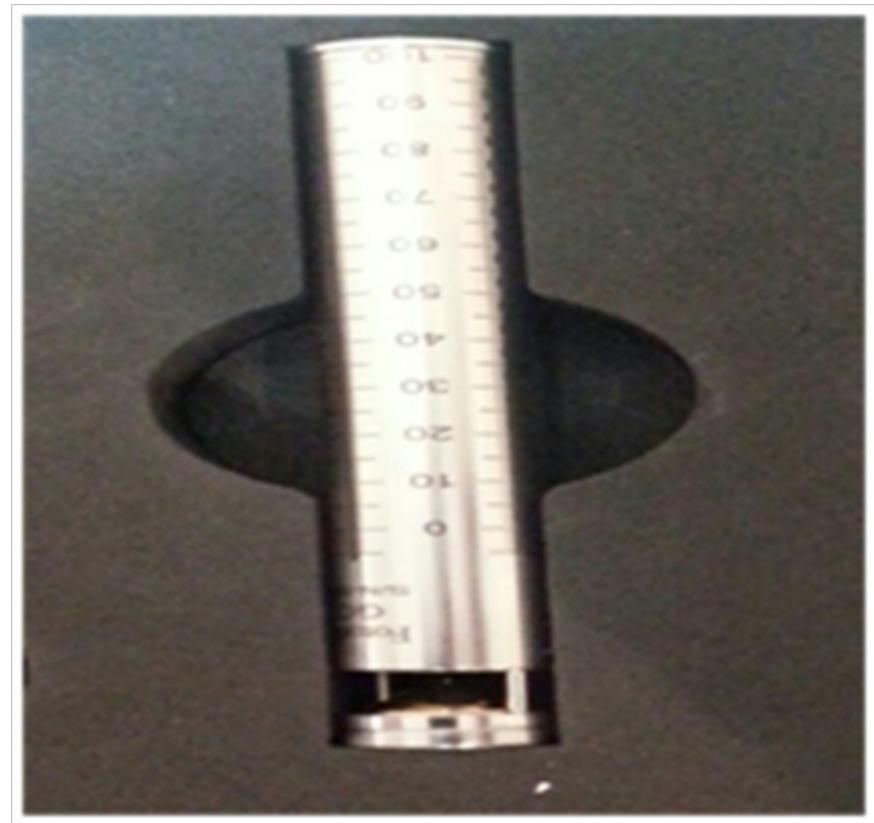

Figure 2 Adapter which enables a precise irradiation of the anterior vaginal.

\section{Discussion}

SUI has a hidden effect on patient's psychological aspect and quality of patient's life. Many interventions are used to treat SUI; some of them are simple as bulking agents and pelvic floor exercise with little not long time lasting effect. Surgical interventions as Burch colposuspenion, tension free trans-vaginal free tape (TVT) 
and tension free vaginal trans-obturator tape (TVTO) are effective in SUI treatment with possible surgical complication, exposure to anesthesia and post-operative hospitalization. ${ }^{12}$ Surgical treatment of SUI specially TVT and TVTO are costly and needs expert, trained surgeons. ${ }^{13}$ Several studies published comparing TVTO procedure with TVT procedure. ${ }^{14}$ A meta-analysis published 3 years ago concluded that both procedures had the same subjective cure rate and were associated with a low incidence of bladder perforation, hematoma development and postoperative storage lower urinary tract symptoms. ${ }^{13}$ Minimal invasive laser is an outpatient procedure, no need for hospital stay or even hospital admission. Most of patients did not feel pain or discomfort during laser procedure, no risks of anesthesia exposure or blood loss during laser procedure. It is simple technique associated with improvement of pelvic floor muscle tone and improvement of SUI symptoms. ${ }^{15,16}$

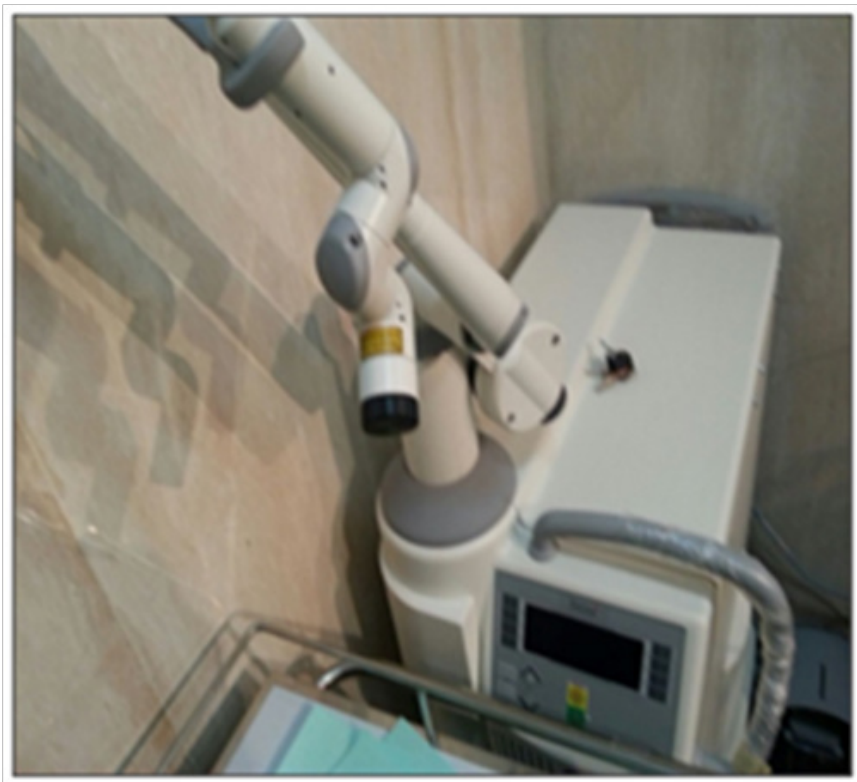

Figure 3 Fotona laser delivery machine.

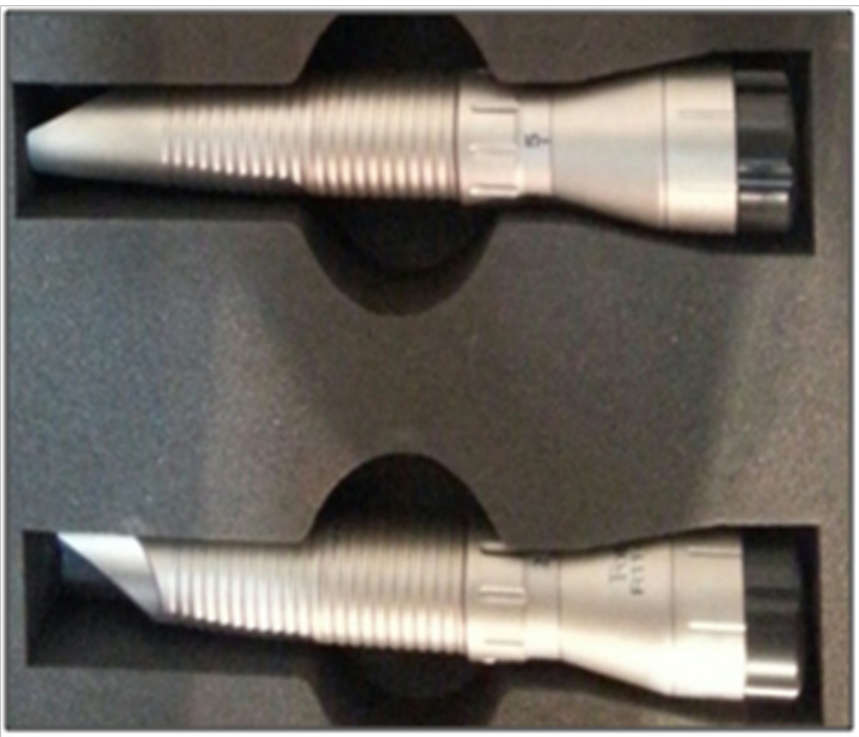

Figure 4 Second phase of the IncontiLaseTM procedure which performed on vestibule and introitus (hand piece $\mathrm{RII}$ and $\mathrm{PSO}_{3}$ ).
Table I Uroflowmetry parameters 6 months after laser treatment compared with pretreatment parameters

\begin{tabular}{|c|c|c|c|}
\hline $\begin{array}{l}\text { Uro- } \\
\text { flowmetery } \\
\text { Parameterts }\end{array}$ & $\begin{array}{l}6 \text { months } \\
\text { after laser } \\
\text { treatment }\end{array}$ & $\begin{array}{l}\text { Before } \\
\text { treatment }\end{array}$ & $\begin{array}{l}\text { P value, significance, } \\
\text { test used for } \\
\text { statistical analysis }\end{array}$ \\
\hline Qavr (ml/second) & II & 3 & $\begin{array}{l}\mathrm{P}=0.03(<0.5), \\
\text { Significant, } \mathrm{X} 2 \text { test }\end{array}$ \\
\hline $\begin{array}{l}\text { Qmax (ml/ } \\
\text { second) }\end{array}$ & 19 & II & $\begin{array}{l}\mathrm{P}=0.2(>0.5), \text { Non- } \\
\text { significant, } \mathrm{X} 2 \text { test }\end{array}$ \\
\hline $\begin{array}{l}\text { Voiding time } \\
\text { (seconds) }\end{array}$ & 24 & 9 & $\begin{array}{l}P=0.02<0.5, \text { Significant, } \\
X 2 \text { test }\end{array}$ \\
\hline $\begin{array}{l}\text { Voided volume } \\
\text { (ml) }\end{array}$ & 156 & 33 & $\begin{array}{l}\mathrm{P}=0(>0.5), \text { Non- } \\
\text { significant, } \mathrm{X} 2 \text { test }\end{array}$ \\
\hline
\end{tabular}

Qavr, average flow rate; $Q \max$, maximum flow rate; $\mathrm{X} 2$, Chi-square test.

Table 2 Cystometry parameters 6 months after laser treatment compared with pretreatment parameters

\begin{tabular}{|c|c|c|c|}
\hline $\begin{array}{l}\text { Cystometry } \\
\text { parameters }\end{array}$ & $\begin{array}{l}6 \text { months } \\
\text { after laser } \\
\text { treatment }\end{array}$ & $\begin{array}{l}\text { Before } \\
\text { treatment }\end{array}$ & $\begin{array}{l}\text { P value, significance, } \\
\text { test used for } \\
\text { statistical analysis }\end{array}$ \\
\hline Residual urine (ml) & 38 & 17 & $\begin{array}{l}\mathrm{P}=0.02(<0.5), \\
\text { Significant, } \mathrm{X}^{2} \text { test }\end{array}$ \\
\hline $\begin{array}{l}\text { PdetQmax (cm } \\
\mathrm{H} 2 \mathrm{O})\end{array}$ & 24 & 16 & $\begin{array}{l}\mathrm{P}=0.2(>0.5), \text { Non- } \\
\text { significant, } \mathrm{X}^{2} \text { test }\end{array}$ \\
\hline First sensation (ml) & 122 & 54 & $\begin{array}{l}\mathrm{P}=0.00 \mathrm{I}(<0.5), \\
\text { Significant, } \mathrm{X}^{2} \text { test }\end{array}$ \\
\hline First desire (ml) & 180 & 75 & $\begin{array}{l}\mathrm{P}=0.0002(<0.5), \\
\text { Significant, } \mathrm{X}^{2} \text { test }\end{array}$ \\
\hline Strong desire (ml) & 250 & 150 & $\begin{array}{l}P=0.02(<0.5), \\
\text { Significant, } X^{2} \text { test }\end{array}$ \\
\hline Urgency (ml) & 340 & 140 & $\begin{array}{l}\mathrm{P}=0(>0.5), \text { Non- } \\
\text { significant, } \mathrm{X}^{2} \text { test }\end{array}$ \\
\hline
\end{tabular}

PdetQmax $\left(\mathrm{cm} \mathrm{H}_{2} \mathrm{O}\right)$, detrusor pressure at maximal flow during voiding cystometry; $\mathrm{X}^{2}$, chi-square

Table 3 Urethral pressure profile parameters 6 months after laser treatment compared with pretreatment parameters

\begin{tabular}{|c|c|c|c|}
\hline $\begin{array}{l}\text { Urethral } \\
\text { pressure } \\
\text { profile } \\
\text { parameters }\end{array}$ & $\begin{array}{l}6 \text { months } \\
\text { after laser } \\
\text { treatment }\end{array}$ & $\begin{array}{l}\text { Before } \\
\text { treatment }\end{array}$ & $\begin{array}{l}\text { P value, significance, } \\
\text { test used for statistical } \\
\text { analysis }\end{array}$ \\
\hline $\operatorname{MUP}\left(\mathrm{cm} \mathrm{H}_{2} \mathrm{O}\right)$ & 32 & 19 & $\begin{array}{l}\mathrm{P}=0 . \mathrm{I}(>0.5) \text {, Non- } \\
\text { significant, } \mathrm{X}^{2} \text { test }\end{array}$ \\
\hline $\begin{array}{l}\text { MUCP }(\mathrm{cm} \\
\left.\mathrm{H}_{2} \mathrm{O}\right)\end{array}$ & 35 & 16 & $\begin{array}{l}P=0.02(<0.5) \text {, Significant, } \\
X^{2} \text { test }\end{array}$ \\
\hline FUL $(\mathrm{cm})$ & 4 & I & $\begin{array}{l}\mathrm{P}=0 . \mathrm{I}(>0.5), \text { Non- } \\
\text { significant, } \mathrm{X}^{2} \text { test }\end{array}$ \\
\hline $\mathrm{CL}(\mathrm{cm})$ & 1.76 & 0.6 & $\begin{array}{l}\mathrm{P}=0.4(>0.5), \text { Non- } \\
\text { significant, } \mathrm{X}^{2} \text { test }\end{array}$ \\
\hline
\end{tabular}




\begin{tabular}{llll} 
Table Continued & & & \\
$\begin{array}{l}\text { Urethral } \\
\text { pressure } \\
\text { profile } \\
\text { parameters }\end{array}$ & $\begin{array}{l}\mathbf{6} \text { months } \\
\text { after laser } \\
\text { treatment }\end{array}$ & $\begin{array}{l}\text { Before } \\
\text { treatment }\end{array}$ & $\begin{array}{l}\text { P value, significance, } \\
\text { test used for statistical } \\
\text { analysis }\end{array}$ \\
\hline $\begin{array}{l}\mathrm{UCPA}\left(\mathrm{cm}^{2}\right. \\
\mathrm{H}\end{array}$ & $53)$ & 38 & $\begin{array}{l}\mathrm{P}=0.2(>0.5), \text { Non- } \\
\text { significant, } \mathrm{X}^{2} \text { test }\end{array}$ \\
$\mathrm{CA}\left(\mathrm{cm}^{2} \mathrm{H}_{2} \mathrm{O}\right)$ & 26 & 22 & $\begin{array}{l}\mathrm{P}=0.6(>0.5), \text { Non- } \\
\text { significant, } \mathrm{X}^{2} \text { test }\end{array}$ \\
\hline
\end{tabular}

MUP, maximal urethral pressure; MUCP, maximal urethral closure pressure; FUL, functional urethral length; $C L$, continence length; UCPA, urethral closure pressure area; $\mathrm{CA}$, continence area; $\mathrm{X}^{2}$ test, chi-square test.

Minimal invasive laser has the advantage of improving of SUI symptoms without any bladder perforation or hematoma. Also, it improves vaginal mucosa tone, regenerates collagen of the extracellular matrix and collagen regains its power to contract with subsequent stabilization of bladder neck. ${ }^{15,16}$ Women refused to participate in this study and small number of studied women were the main limitation faced during this study and further studies include large population number are needed in the future to stabilize definite role of minimal invasive laser in treatment of female SUI.

\section{Acknowledgments}

None.

\section{Conflicts of interest}

The authors declare there is no conflict of interests.

\section{References}

1. Novara G, Artibani W, Barber MD, et al. Updated systematic review and meta-analysis of the comparative data on colposuspensions, pubovaginal slings and midurethral tapes in the surgical treatment of female stress urinary incontinence. Eur Urol. 2010;58(2):218-238.

2. Serati M, Ghezzi F, Cattoni E, et al. Tension-free vaginal tape for the treatment of urodynamic stress incontinence: efficacy and adverse effects at 10-year follow-up. Eur Urol. 2012;61(5):939-946.

3. Casey BM, Schaffer JI, Bloom SL, et al. Obstetric antecedents for postpartum pelvic floor dysfunction. Am J Obstet Gynecol. 2005;192:1655-1662.
4. Nilsson CG, Falconer C, Rezapour M. Seven-year follow-up of the tension-free vaginal tape procedure for treatment of urinary incontinence. Obstet Gynecol. 2004;104(6):1259-1262.

5. Chêne G, Amblard J, Tardieu AS, et al. Long-term results of tension-free vaginal tape (TVT) for the treatment of female stress urinary incontinence. Eur J Obstet Gynecol Reprod Biol. 2007;134(1):87-94.

6. Avery K, Donovan J, Peters TJ, et al. ICIQ: a brief and robust measure for evaluating the symptoms and impact of urinary incontinence. Neurourol Urodyn. 2004;23(4):322-330.

7. Beltram M, Drnovsek-Olup B. Histological and biomolecular analysis of new collagen synthesis after "smooth" mode Er:YAG laser skin resurfacing. Lasers Surg Med. 2004;(Suppl 16):56.

8. Utley DS, Koch RJ, Egbert BM. Histologic analysis of the thermal effect on epidermal and dermal structures following treatment with the superpulsed $\mathrm{CO}_{2}$ laser and the erbium: YAG laser: an in vivo study. Lasers Surg Med. 1999;24(2):93-102.

9. Tanzi EL, Alster TS. Single-pass carbon dioxide versus multiple-pass Er:YAG laser skin resurfacing: a comparison of postoperative wound healing and side-effect rates. Dermatol Surg. 2003;29(1):80-84.

10. Perhavec T, Diaci J. Comparison of Er :YAG and Er,Cr :YSGG dental lasers. J Oral Laser Appl. 2008;8(2):87-94.

11. Pelvic Organ Prolapse. A pocket reference guide, human anatomy spiral flip book, New York; 2006.

12. Dierickx CC, Khatri KA, Tannous ZS, et al. Micro-fractional ablative skin resurfacing with two novel erbium laser systems. Lasers Surg Med. 2008;40(2):113-123.

13. Jakobowski A, Kim CMH. Urinary incontinence \& sexual dysfunction, educational book for women. 2010.

14. Rogers RG, Coates KW, Kammerer-Doak D, et al. A short form of the Pelvic Organ Prolapse/Urinary Incontinence Sexual Questionnaire (PISQ-12). Int Urogynecol J Pelvic Floor Dysfunct. 2003;14(3):164-168.

15. Drnovsek-Olup B, Beltram M, Pizem J. Repetitive Er:YAG laser irradiation of human skin: a histological investigation. Lasers Surg Med. 2004;35(2):146-151.

16. Rivera M. Laser treatments for Vaginal Tightening and Stress Urinary Incontinence, oral presentation at first Symposium of Laser and health Academy, Gozd Matruljek, Slovenia; 2011. 